УДК 351

DOI: https://doi.org/10.26642/jen-2021-3(97)-47-52

\author{
В.В. Микитенко, д.е.н., проф. \\ I.В. Драган, д.держ.упр., с.н.с. \\ ДУ «Інститут економіки природокористування та сталого розвитку НАН України»
}

І.О. Драган, д.держ.упр., проф.

Державний університет «Житомирська політехніка»

\title{
Формування механізмів управління забезпеченням сталого господарювання
}

У статті сформовано й побудовано архітектуру замкнено-ланцюгового механізму управління забезпеченням сталого господарювання, щчо виконано за методологією проєктування та структурно-логічної організації управлінських методів $і$ засобів у контексті забезпечення стійкості господарських систем за двома групами системоутворюючих (системногомеостатичних) підмеханізмів системо-організаційного та системно-функціонального (репаративно-алармовий, кібернетично-просторовий) комплексів. Удосконалено структуру, зміст $і$ функиії узагальненого замкнено-ланцююгового механізму управління забезпеченням сталого господарювання, до складу якого входять системоутворюючі підмеханізми: адаптаційно-стабілізаційний, репаративно-алармовий, бінарно-прогностичний, кібернетичнопросторовий, які убезпечують синхронний перебіг параболічних подій із інтенсифікачї̈ прочесів обміну-перерозподілу ресурсів, резервів і можливостей (потенціалу гомеостазу) у внутрішньому середовищі господарської системи, реалізація дії яких відбувається за рахунок стабілізачії (генерування ламінарності) протікання потоків чотирьох, базових для сталого розвитку, прочесів (економічної, виробничої, природно-ресурсної та сочієтальної природи). Побудовано багаторівневу схему бінарного формування, переформатування та реалізації дії замкненоланцңюгового механізму управління забезпеченням сталого господарювання, запровадження у практику замкнутих циклів управління, щฺо передбачає побудову системоутворюючих регуляторів у двох паралельних площчинах - структурно-організаційного й структурнофункціонального комплексів гомеостатичних підмеханізмів управління забезпеченням сталого господарювання, а згодом із майже одночасним «запуском» адаптаційно-стабілізаційного й бінарно-прогностичного підмеханізмів, за якими й синхронне введення репаративно-алармового й кібернетично-просторового підмеханізмів.

Ключові слова: механізми управління; просторова система управління; стале господарювання; сталий розвиток; управлінські методи.

Постановка проблеми. Протягом більше ніж півстоліття свого існування концепція сталого розвитку користується широкою популярністю серед наукової громадськості. На сьогоднішній день іiі ідеї наявні у більшості соціально-економічних, екологічних та політичних програмах розвитку як на регіональному, так і на державному рівнях. Сталий розвиток декларується як новий імператив для нашого та наступного поколінь, нова сходинка розвитку, на яку має зійти людство у своєму поступі, що вимагає переосмислення існуючих цінностей, кардинальної зміни світогляду, пріоритетів, етичних й інших норм та форм раціональності. Стійкість $є$ однією 3 найбільш значущих характеристик господарських систем різного рівня. Особливу важливість проблематика забезпечення стійкості господарських систем набуває на тлі стрімкого ускладнення економічних відносин, а також існуючих кризових процесів. Отже, з урахуванням значущості управлінського аспекту необхідно звернути увагу на існуючі теоретико-методологічні підходи, які розкривають механізми забезпечення стійкості господарських систем. Розробка цієї проблематики органічно пов'язана з еволюцією методологічних напрямів системного підходу.

Аналіз останніх досліджень та публікацій. Теоретичним, методологічним і концептуальним проблемам формування механізмів управління забезпеченням сталого господарювання присвячено наукові праці О.Алимова, О.Амоші, Б.Данилишина, І.Бистрякова, І.Лицура, М.Чумаченко, С.Шкарлета та інших вчених-економістів. Методичні підходи щодо дослідження проблематики і моделювання траєкторії формування стратегій економічного та соціального розвитку регіонів розкрито у роботах І.Ансоффа, А.Касич, М.Портера, А.Стікленда, А.Томпсона, О Федоніна, М.Хвесика.

Мета статті - визначити та ідентифікувати управлінські пріоритети забезпечення механізму сталого господарювання.

Викладення основного матеріалу. Особливості розбудови механізмів управління забезпеченням сталого господарювання в Україні зумовлені специфічністю сучасних умов генерування гомеостатичних здатностей у господарських систем за чотирма рівнями управління гомеостазом. Вказане й передбачає необхідність проєктування відповідних чотирьом етапам формування в межах утворень гомеостатичних 
властивостей еволюційної, структурної, резистентної та системної природи. 3 огляду на свідчення, зазначені й обгрунтовані дослідниками у [1; 2], конститутивно-ключові положення групування гомеостатичних властивостей господарських систем за чотирма рівнями складності у контексті управління забезпеченням гомеостазу в їхніх межах, слід визнати, що для забезпечення:

- еволюційного гомеостазу в межах господарської системи: необхідним є сформування адаптаційної, стабілізаційної та інерційної властивостей;

- структурного гомеостазу - стабілізаційної, адаптаційної, алармової та репаративної властивостей;

- резистентного гомеостазу - когнітивно-інформаційної, стабілізаційної, репаративної, регенеративної, бінарної, прогностичної та специфічної управлінської властивостей;

- системного гомеостазу - стабілізаційної, організаційно-економічної, кінематичної, кібернетичної та алармової властивостей.

Фактично має бути побудовано єдиний замкнено-ланцюговий механізм управління забезпеченням сталого господарювання (рис. 1), до складу якого входять системоутворюючі підмеханізми: адаптаційностабілізаційний, репаративно-алармовий, бінарно-прогностичний, кібернетично-просторовий, які убезпечують синхронний перебіг параболічних подій із інтенсифікації процесів обміну-перерозподілу ресурсів, резервів і можливостей (потенціалу гомеостазу) у внутрішньому середовищі господарської системи, реалізація дії яких відбувається за рахунок стабілізації (генерування ламінарності) протікання потоків чотирьох базових для сталого розвитку процесів (економічної, виробничої, природно-ресурсної та соцієтальної природи).

Відтак з метою формалізації структури та етапів формування і реалізації дії узагальненого замкненоланцюгового механізму управління забезпеченням сталого господарювання у складі чотирьох системоутворюючих підмеханізмів (адаптаційно-стабілізаційного, репаративно-алармового, бінарнопрогностичного, кібернетично-просторового) вважаємо за доцільне визначити базові функції регуляторів. Враховуючи напрацювання, які наведено дослідниками у попередніх науково-прикладних розробках $[1 ; 2]$, за якими побудовану схему замкненого оберненого взаємозв'язку та взаємозалежностей між гомеостатичними властивостями господарських систем, необхідних для генерування стійкості цих систем, вважаємо за доцільне вказати таке:

- замкнено-ланцюговий механізм управління слід умовно поділити на дві групи системоутворюючих (тобто системно-гомеостатичних) підмеханізмів: а) системно-організаційні (адаптаційно-стабілізаційний, бінарно-прогностичний); б) системно-функціональні (репаративноалармовий, кібернетично-просторовий);

- функції реалізації дії у контексті забезпечення результативності механізму управління визначаються переліком гомеостатичних властивостей, які необхідно сформувати у внутрішньому середовищі господарських систем.

3 огляду на вказані вище обгрунтування, переконання авторів цього дослідження, можна виокремити два рівні складності досягнення результативності управління 3 метою забезпечення сталого господарювання. Вони залежать саме від напрямів та об’єктів локалізації зусиль і, відповідно, масштабів та глибини охоплення. Зокрема:

I) структурно-організаційний комплекс регуляторів i важелів впливу, відповідно до якого відбувається реалізація дії спочатку адаптаційно-стабілізаційного підмеханізму, задля генерування еволюційного гомеостазу господарських систем, а надалі - репаративно-алармового, $з$ метою досягнення структурного гомеостазу;

II) структурно-функціональний рівень складності управління, в межах якого розбудовуються i «запускаються», майже одночасно, бінарно-прогностичний і кібернетично-просторовий підмеханізми.

Виходячи 3 цього, загальну схему замкнено-ланцюгового механізму управління забезпеченням сталого господарювання можна репрезентувати у вигляді багаторівневої схеми його формування, переформатування та реалізації дії, яка наведена на рисунку 1. 


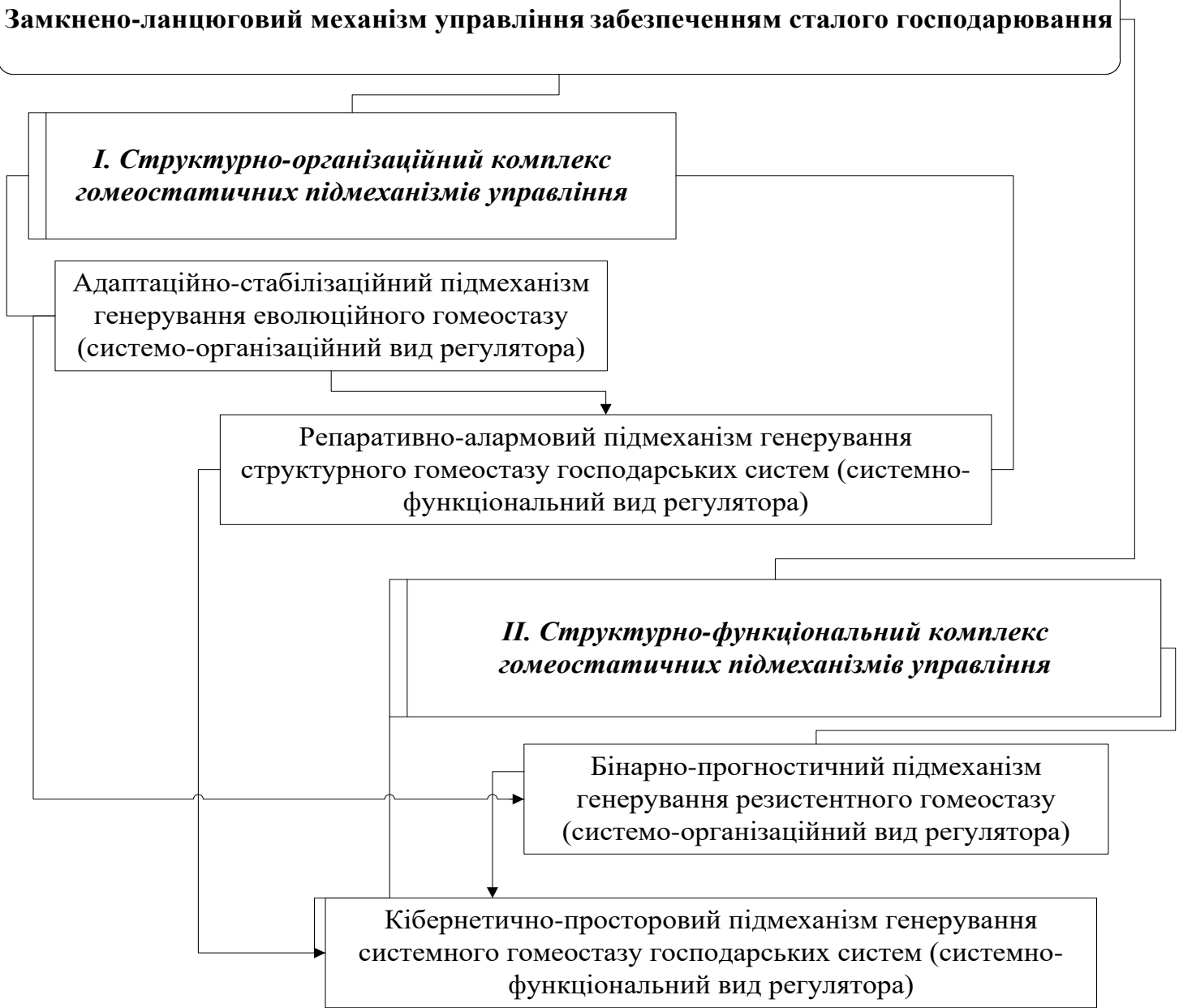

Рис. 1. Багаторівнева схема формування, переформатування та реалізаџії дї замкнено-ланцюгового механізму управління забезпеченням сталого господарювання (авторська розробка)

Фактично ж, на першому етапі структурно-організаційного управління формується та запроваджується адаптаційно-стабілізаційний підмеханізм генерування еволюційного гомеостазу (системно-організаційний вид регулятора), який на наступному етапі інкорпорується до репаративноалармового підмеханізму генерування структурного гомеостазу господарських систем (системнофункціональний вид регулятора). Таким чином, досягнення структурного гомеостазу передбачає еволюційність трансформації і перебудови внутрішнього середовища господарських систем.

А надалі відбувається «запуск» бінарно-прогностичного підмеханізму генерування резистентного гомеостазу (системно-організаційний вид регулятора) i, майже одночасно 3 ним, кібернетичнопросторовий підмеханізм генерування системного гомеостазу господарських систем (системнофункціональний вид регулятора). Багаторівневий характер замкнено-ланцюгового механізму управління забезпеченням сталого господарювання, множинність складу структурно-організаційного та структурнофункціонального комплексів гомеостатичних підмеханізмів управління, наявність у межах останніх специфічних системно-організаційних та системно-функціональних регуляторів цілеоріснтованого впливу, а між ними - транспортуючих й інкорпораційних ланок задля досягнення визначених i обгрунтованих суб'єктами управління результатів - новий напрям наукових розробок, стосовно якого простежується тенденція до якісного удосконалення тематичного, методологічного, історикофактологічного забезпечення об’єктивної рефлексії проблематики сталого розвитку у національній науковій думці.

Проте усвідомлення явища забезпечення сталого господарювання за домінантами чотирьох видів гомеостазу - новий зріз дослідження можливостей його забезпечення в умовах ресурсних обмежень, переформатування суспільно-політичного, техніко-технологічного, еколого- й соціально-економічного метапростору державного утворення. Вказане здатне поглибити системне бачення процесів сталого розвитку в Україні у динаміці формування, трансляції й освоєння її стратегічного потенціалу (а у його 
межах - природно-ресурсних активів) і практичних акцій суб’єктів державного (у т. ч., регіонального і місцевого) управління як у контексті реалізації НЕI, так і на міжнародній арені.

Інтерпретація розробниками структури замкнено-ланцюгового механізму управління забезпеченням сталого господарювання (рис. 1) вимагає формалізації його складових за обома рівнями складності 3 деталізацією функцій реалізації дії та принципів формування.

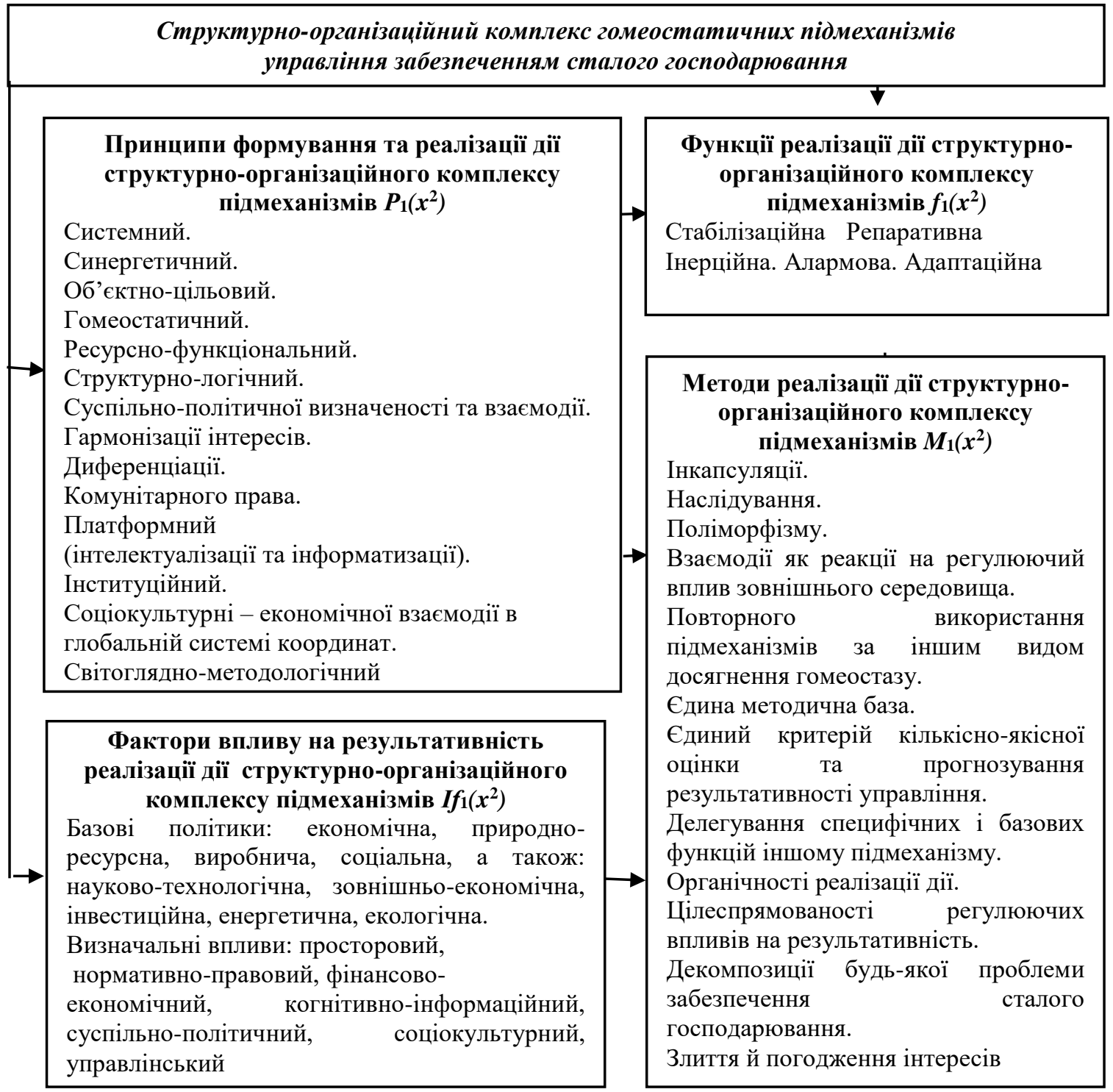

Рис. 2. Вирішальні елементи, щз убезпечують формування та реалізацію дії структурно-організаційного комплексу гомеостатичних підмеханізмів управління забезпеченням сталого господарювання (авторська розробка)

Так, зокрема, репрезентуємо нижче й наступні авторські напрацювання, за якими визнано нагальність $\mathrm{i}$ доцільність використання методу синтезу з прийомами компонування цілісної системи архітектурного об'єкта (господарської системи) і засобами гармонізації об'єкта проєктування з навколишнім середовищем. Вказане дозволило формалізувати перелік принципів формування та реалізації дії, специфічні функції, фактори і найвагоміші важелі впливу на результативність управління, а також методи, що убезпечують досягнення цілі, як структурно-організаційним комплексом гомеостатичних підмеханізмів управління забезпеченням сталого господарювання (рис. 2), так і структурно-функціональним. 3 огляду на визначені у контексті формування та реалізації дії структурно-організаційного комплексу гомеостатичних підмеханізмів управління забезпеченням сталого господарювання (рис. 2), у складі адаптаційностабілізаційного підмеханізму (генерування еволюційного гомеостазу) і репаративно-алармового (досягнення структурного гомеостазу) господарських систем, важливими є, крім описаних і деталізованих дослідниками як у попередній розробці [2], так і у наукових працях [5-7], такі вихідні положення: 
- домінанти комунітарного права. Зазначимо, що комунітаризм (від англ. community спільнота, громада; община; ознаками комунітаризму є спільне існування, кооперація і взаємодія, спільні інтереси) - це обстоювання й реформування соціального устрою, за якого індивіди пов'язані спільними цінностями, які сприяють тісним зв'язкам у спільноті. Критикуючи індивідуальну ліберальну антропологію, яка недооцінює значення тієї обставини, що соціальна свобода може бути реалізована лише в умовах суспільства, виокремлено асоціативну як макро-, так і мікроспільноту, які держава ані опікує, ані контролює, але вони існують як самодостатні агрегації (більше ніж просто сума) індивідів. При цьому основна мета реалізації принципів комунітарного права - забезпечити загальне благо як визначальне право об'єднаних утворень, створених на основі того, що учасники такого комунітарного об’єднання (правової спільноти) передають певні суверенні права та повноваження спільному виборному управлінському органові й наділяють його певною компетенцією щодо реалізації своїх прав.

Не дивлячись на те, що вихідні принципи комунітарного права мають певні переваги [7] (реалізує орган, який юридично непідконтрольний і приймає обов'язкові рішення, що не залежать від негативних наслідків інтересів однієї або декількох держав; суб'єкти комунітарного об'єднання постають в особливій ролі, а не як представники корелянтів; органи комунітарного об'єднання приймають рішення більшістю голосів шляхом пропорційного голосування, керуючись інтеграційним правом із потужною юридичною гарантією), однак використовувати в цілому у практиці господарювання усталені комунітарні методи (зокрема, базові за Монне Шумана), автори цього дослідження не вважають за доцільне. Оскільки до складу методів комунітарного права належать і такі, які суперечать HЕI. До останніх нами включено (тобто, виключено зі списку): федеративні цілі; обмеження державного суверенітету; створення наднаціональних органів влади тощо. Проте такі комунітарні методи, як: поступовість та поетапність інтеграції й інкорпорації; забезпечення злиття й узгодження невід'ємних економічних, суспільних, технологічних, виробничих, природно-ресурсних і соціальних інтересів; інтеграція як засіб вирішення суспільно-політичних проблем - вважаємо нагальними для їх врахування та використання в системі управління забезпеченням сталого господарювання;

соціокультурні принции економічної взаємодії в глобальній системі координат. Враховуючи новітні світоглядно-методологічні трансформації суспільно-політичної, макроекономічної, технологічної й медико-соціальної перебудови метапростору, слід визначити ціннісну шкалу смислів у ступені мультидисциплінарних оцінок «нової реальності», сформувати адекватний реальним процесам критерій, за яким можна характеризувати сталий розвиток завдяки об'єктивізації дослідницьких суджень. Виникаюча проблема співвідношення та гармонізації інтересів суб'єктів сталого господарювання вирішується лише у просторі інформаційно-комунікативної та когнітивно-інформаційної діяльності. А основою діалогу, обміну й узгодження $€$ «багатосуб'єктність» цих процесів, а результатом має бути збіг «смислових центрів» під час обміну діями породження, викладення змісту інтересів й інтерпретації сутності вимог.

Висновки і перспективи подальших досліджень. У статті сформовано й побудовано архітектуру замкнено-ланцюгового механізму управління забезпеченням сталого господарювання. Вказане виконано 3 використання методології проєктування та структурно-логічної організації управлінських методів і засобів у контексті забезпечення стійкості господарських систем за двома групами системоутворюючих (системно-гомеостатичних) підмеханізмів системно-організаційного та системно-функціонального (репаративно-алармовий, кібернетично-просторовий) комплексів. Розбудова та застосування цих комплексів дозволяє, зокрема: а) на першому етапі - реалізацію дії структурно-організаційного комплексу: адаптаційно-стабілізаційного підмеханізму - задля генерування еволюційного гомеостазу, а надалі репаративно-алармового - 3 метою досягнення структурного гомеостазу; б) на другому етапі виконати «запуск» структурно-функціонального комплексу: бінарно-прогностичного підмеханізму генерування резистентного гомеостазу (системно-організаційний вид регулятора) i, майже одночасно 3 ним, запустити й кібернетично-просторовий підмеханізм - із метою генерування системного гомеостазу господарських систем (системно-функціональний вид регулятора).

Поряд із зазначеним дослідниками удосконалено структуру, зміст і функції узагальненого замкненоланцюгового механізму управління забезпеченням сталого господарювання. До його складу належать системоутворюючі підмеханізми: адаптаційно-стабілізаційний, репаративно-алармовий, бінарнопрогностичний, кібернетично-просторовий, які убезпечують синхронний перебіг параболічних подій із інтенсифікації процесів обміну-перерозподілу ресурсів, резервів і можливостей (потенціалу гомеостазу) у внутрішньому середовищі господарської системи, реалізація дії яких відбувається за рахунок стабілізації (генерування ламінарності) протікання потоків чотирьох, базових для сталого розвитку, процесів (економічної, виробничої, природно-ресурсної та соцієтальної природи).

Інтерпретація вихідних положень новоствореної теорії сталого господарювання, дозволили:

а) побудувати багаторівневу схему бінарного формування, переформатування та реалізації дії замкненоланцюгового механізму управління забезпеченням сталого господарювання; б) розробити рекомендації щодо запровадження у практику замкнутих циклів управління. Щодо останнього, то необхідно зауважити, що запровадження у практику управління передбачає синхронну розбудову системоутворюючих регуляторів у двох паралельних площинах. А саме: структурно-організаційного й структурно-функціонального комплексів 
гомеостатичних підмеханізмів управління забезпеченням сталого господарювання, а згодом із майже одночасним «запуском» адаптаційно-стабілізаційного й бінарно-прогностичного підмеханізмів, за яким й виконується паралельне введення репаративно-алармового й кібернетично-просторового підмеханізмів.

\section{Список використаної літератури:}

1. Алимов О.М. Каскади регіональних соціально-економічних систем: формування та розвиток : монографія / О.М. Алимов, О.О. Демешок, І.В. Драган. - К. : ДУ «Інститут економіки природокористування та сталого розвитку НАН України», 2016. - $278 \mathrm{c.}$

2. Бистряков I.К. Етапи розбудови в Україні територіальних природно-господарських округів / I.К. Бистряков, В.B. Микитенко // Економіка, управління, інновації / Серія : Економічні науки. - Житомир : Вид-во ЖДУ ім. І.Франка, 2018. - Вип. 2 (23) [Електронний ресурс]. - Режим доступу : http://nbuv.gov.ua/UJRN/eui_2018_2_4.

3. Бияков О.А. Экономическое пространство: сущность, функции, свойства / О.А. Бияков // Вестник КузГТУ.2004. - № 2. - C. 101-108 [Электронный ресурс]. - Режим доступа : https://cyberleninka.ru/article/n/ekonomicheskoe-prostranstvo-suschnost-funktsii-svoystva.

4. Бутко М.П. Інституціональні засади модернізації сфери зайнятості в умовах децентралізації владних повноважень / М.П. Бутко, О.В. Попело // Регіональна економіка. - 2016. - № 4 (82). - С. 6-14.

5. Драган I.B. Інвестиційне забезпечення екологічних проектів суб'єктів господарювання / I.B. Драган // Агросвіт. - 2019. - № 5. - С. 41-46.

6. Микитенко B.B. Побудова структурно-логічної схеми вирішення проблем формування системи механізмів управління природними ресурсами в Україні / B.B. Микитенко // Економіка, управління, інновації / Серія : Економічні науки. - Житомир : Вид-во ЖДУ університету ім. І.Франка, 2017. - № 1 (20) [Електронний pecypc]. - Режим доступу : http://nbuv.gov.ua/UJRN/eui_2017_1_8

7. Національна парадигма сталого розвитку України : монографія / М.А. Хвесик, О.М. Алимов, А.В. Голян та $i н$. ; за заг. ред. академіка НАН України, д.т.н., проф., заслуженого діяча науки і техніки України Б.С. Патона ; вид. 2-ге, перероб. і доп. - К. : Державна установа «Інститут економіки природокористування та сталого розвитку Національної академії наук України», 2016. 72 с.

\section{References:}

1. Alymov, O.M., Demeshok, O.O. and Dragan, I.V. (2016), Kaskady regional'nyh social'no-ekonomichnyh system: formuvannja ta rozvytok, monografija, DU «Instytut ekonomiky pryrodokorystuvannja ta stalogo rozvytku NAN Ukrai'ny». Kyiv, 278 p.

2. Bystrjakov, I.K. and Mykytenko, V.V. (2018), «Etapy rozbudovy v Ukrai'ni terytorial'nyh pryrodno-gospodars'kyh okrugiv», Ekonomika, upravlinnja, innovacii', Serija Ekonomichni nauky, Vyd-vo ZhDU im. I.Franka, Zhytomyr, Vol. 2 (23), [Online], available at: http://nbuv.gov.ua/UJRN/eui_2018_2_4.

3. Biyakov, O.A. (2004), «Ekonomicheskoe prostranstvo: sushchnost', funktsii, svoistva», Vestnik KuzGTU, Vol. 2, pp. 101108, [Online], available at: https://cyberleninka.ru/article/n/ekonomicheskoe-prostranstvo-suschnost-funktsii-svoystva

4. Butko, M.P. and Popelo, O.V. (2016), «Instytucional'ni zasady modernizacii' sfery zajnjatosti v umovah decentralizacii' vladnyh povnovazhen'», Regional'na ekonomika, Vol. 4 (82), pp. 6-14.

5. Dragan, I. (2019), «Investycijne zabezpechennja ekologichnyh proektiv sub'jektiv gospodarjuvannja», Agrosvit, Vol. 5, pp. 41-46.

6. Mykytenko, V.V. (2017), «Pobudova strukturno-logichnoi' shemy vyrishennja problem formuvannja systemy mehanizmiv upravlinnja pryrodnymy resursamy v Ukrai'ni», Ekonomika, upravlinnja, innovacii', Serija Ekonomichni nauky, Vyd-vo ZhDU universytetu im. I.Franka, Zhytomyr, Vol. 1 (20), [Online], available at: http://nbuv.gov.ua/UJRN/eui_2017_1_8

7. Hvesyk, M.A., Alymov, O.M., Goljan, A.V. ta in. (2016), Nacional'na paradygma stalogo rozvytku Ukrai'ny, monografija, in Paton, B.Je. (ed.), vyd. 2-ge, pererob. i dop., Derzhavna ustanova «Instytut ekonomiky pryrodokorystuvannja ta stalogo rozvytku Nacional'noi' akademii' nauk Ukrai'ny», K., 72 p.

Микитенко Вікторія Володимирівна - доктор економічних наук, професор, головний науковий співробітник відділу методології сталого розвитку ДУ «Інститут економіки природокористування та сталого розвитку НАН України».

https:// orcid.org/0000-0002-8212-9777.

Наукові інтереси:

- розробка й обгрунтування комплексу принципів, завдань i форм забезпечення сталого господарювання за урахування масштабів нагромадження загроз і ризиків різної природи.

Драган Ірина Василівна - доктор наук з державного управління, старший науковий співробітник відділу методології сталого розвитку ДУ «Інститут економіки природокористування та сталого розвитку НАН України». https:// orcid.org/0000-0002-6906-5000.

Наукові інтереси:

- науково-прикладні дослідження забезпечення загальної соціо-, еколого-економічної рівноваги та рекомендації щодо організації сталого господарювання.

Драган Іван Олександрович - доктор наук з державного управління, професор Державного університету «Житомирська політехніка».

Наукові інтереси:

- державне управління ЖКГ; державне регулювання у сфері природокористування; 